\title{
Malaria epidemiology in the Ahafo area of Ghana
}

\author{
Kwaku P Asante ${ }^{1 *}$, Charles Zandoh ${ }^{1}$, Dominic B Dery ${ }^{1}$, Charles Brown², George Adjei ${ }^{1}$, Yaw Antwi-Dadzie ${ }^{3}$, \\ Martin Adjuik ${ }^{4}$, Kofi Tchum', David Dosoo', Seeba Amenga-Etego ${ }^{1}$, Christine Mensah" ${ }^{5}$, \\ Kwabena B Owusu-Sekyere ${ }^{3}$, Chris Anderson ${ }^{3}$, Gary Krieger ${ }^{6}$ and Seth Owusu-Agyei ${ }^{1}$
}

\begin{abstract}
Background: Plasmodium falciparum malaria remains endemic in sub-Saharan Africa including Ghana. The epidemiology of malaria in special areas, such as mining areas needs to be monitored and controlled. Newmont Ghana Gold Limited is conducting mining activities in the Brong Ahafo Region of Ghana that may have an impact on the diseases such as malaria in the mining area.
\end{abstract}

Methods: Prior to the start of mining activities, a cross-sectional survey was conducted in 2006/2007 to determine malaria epidemiology, including malaria parasitaemia and anaemia among children $<5$ years and monthly malaria transmission in a mining area of Ghana.

Results: A total of 1,671 households with a child less than five years were selected. About $50 \%$ of the household heads were males. The prevalence of any malaria parasitaemia was $22.8 \%$ ( $95 \% \mathrm{Cl} 20.8$ - 24.9). Plasmodium falciparum represented $98.1 \%$ (95\% Cl 96.2 - 99.2) of parasitaemia. The geometric mean $P$. falciparum asexual parasite count was 1,602 (95\% Cl 1,140-2,252) and 1,195 (95\% Cl $985-1,449)$ among children < 24 months and $\geq$ 24 months respectively. Health insurance membership (OR 0.60, 95\% Cl $0.45-0.80, p=0.001)$ and the least poor (OR 0.57, 95\% Cl $0.37-0.90, p=0.001$ ) were protected against malaria parasitaemia. The prevalence of anaemia was high among children < 24 months compared to children $\geq 24$ months (44.1\% (95\% Cl $40.0-48.3$ ) and 23.8\% (95\% Cl $21.2-26.5$ ) respectively. About $69 \%$ (95\% Cl $66.3-70.9$ ) of households own at least one ITN. The highest EIRs were record in May 2007 (669 ib/p/m) and June 2007 (826 ib/p/m). The EIR of Anopheles gambiae were generally higher than Anopheles funestus.

Conclusion: The baseline malaria epidemiology suggests a high malaria transmission in the mining area prior to the start of mining activities. Efforts at controlling malaria in this mining area have been intensified but could be enhanced with increased resources and partnerships between the government and the private sector.

\section{Background}

Plasmodium falciparum malaria remains endemic in sub-Saharan Africa [1]. In Ghana, the burden of malaria remains high with about 323 per 1,000 cases reported among children < 5 years in 2008; and there is limited evidence of a decrease in recent years (2002 - 2008) [2]. Malaria studies carried out in the middle belt of Ghana report of high transmission of approximately 269 infective bites per person per year and a parasite prevalence of not less than $50 \%$ at all times in the year among children $<5$ years [3]. The burden of malaria in Ghana and other endemic countries will continue to result in

\footnotetext{
* Correspondence: kwakupoku.asante@kintampo-hrc.org

'Kintampo Health Research Centre, Ghana Health Service, Ministry of Health,

P. O. Box 200, Kintampo, Ghana

Full list of author information is available at the end of the article
}

anaemia, cerebral malaria, and severe malaria, if the use of currently available tools for malaria interventions such as rapid diagnosis and appropriate treatment, use of insecticide-treated nets (ITNs) and indoor residual spraying are not intensified as part of the strategies to control malaria. A complex matrix of factors could mitigate the successful use of the available tools; of special note are access to health care, household socioeconomic status, parental formal education, health education about malaria control and nutritional status of individuals. However, there have been reports of encouraging malaria control efforts in some countries in sub-Saharan Africa, including Zanzibar [4], Kenya [5,6] and Tanzania [7], which can be replicated in other African countries given the resources from public and private partnerships and political commitment available recently.

\section{Biomed Central}


Newmont Ghana Gold Limited, a mining company in Ghana[8] recognizes that its mining activities may have an impact on malaria and other public health diseases in the mining area. For example, mining activities could alter the breeding potential of mosquitoes as well as increase migration into the mining area and this could precipitate poor environmental factors that may lead to diseases including malaria. Alternatively, environmental alterations as a result of urbanization and the mining activities may decrease mosquito breeding sites and, therefore, the burden of malaria.

With this realization, the Ghana Health Service in partnership with Newmont Ghana Gold Limited conducted a household and malaria epidemiology study as a baseline prior to the start of mining activities of Newmont Ghana Gold Limited in 2006/2007 to plan and evaluate malaria control programme within the area. This effort to control malaria in a mining area builds on a similar partnership in another mining area in Obuasi, Ghana that has led to a successful malaria control programme in the area [9]. This baseline malaria epidemiological data will be used for monitoring and evaluating malaria interventions specifically targeted at the mining area. The Ahafo baseline data are being reported in further attempts to contribute to the body of data required for monitoring global malaria burden.

\section{Methods}

\section{Study area}

The study was carried out in four districts in the Brong Ahafo Region of Ghana; the Asutifi District (between latitudes $6^{\circ} 40^{\prime}$ and $7^{\circ} 15^{\prime}$ North and Longitudes $2^{\circ} 15^{\prime}$ and $2^{\circ} 45^{\prime}$ West), the Tano North and South (Tano N/S) Districts (between latitudes $7^{\circ} 00^{\prime} \mathrm{N}$ and $7^{\circ} 25^{\prime} \mathrm{N}$ and between longitudes $1^{\circ} 45 \mathrm{~W}$ and $2^{\circ} 30 \mathrm{~W}$ ), and the Techiman municipality (between latitudes $7^{\circ} 31^{\prime} \mathrm{N}$ and $8^{\circ} 0^{\prime} \mathrm{N}$ and between longitudes $1^{\circ} 60 \mathrm{~W}$ and $2^{\circ} 00 \mathrm{~W}$ ). The study areas are in the wet semi-equatorial forest zone where the mean annual rainfall is about $1,200 \mathrm{~mm}$ per annum. Farming of cash crops, such as Cocoa, Oil Palm, Coffee are the major economic activity in the study communities. All health facilities in the study area implement both clinical and public health services under the supervision of the Brong Ahafo Regional Health Directorate. Malaria is the leading cause of morbidity and mortality in the region. About eighty percent of residents in the study area belong to the Akan ethnicity.

\section{Study design and methods}

A household cross-sectional study was carried out between July 2006 and March 2007 to determine baseline household morbidity and malaria transmission prior to the start of mining activities in the area. The districts in the mining area were categorized into two; the
Impact area involving communities within the Asutifi, and Tano N/S districts whose health and/or socio-economic indices are likely to be affected by mining activities being undertaken and located within approximately $25 \mathrm{Km}$ radius from the mine sites. The Non-impact area representing communities within the Asutifi, Tano North or Tano South districts that are not likely to be affected by the mining activities and located more than $25 \mathrm{Km}$ from the mines site (Figure 1). The Techiman municipality was purposively selected as a control area without mining activities but under the same local political and health administration as the other districts. The control area was selected for future comparisons after the beginning of mining activities. Within each area, communities were purposively selected based on geographical location to ensure representation of all locations within each area. Eleven (11) out of twenty (20); thirteen (13) out of nineteen (19) and eight (8) out of eighteen (18) communities were selected to represent the study areas in the Asutifi, Tano N/S and Techiman areas respectively.

\section{Household selection}

All households in the selected communities were enumerated and encoded into a database. Each household member in the community including children less than five (5) years was given a unique identification number as part of the household morbidity survey. All households who were respondents for the household morbidity survey and with children less than five (5) years in the database formed the sampling frame. One child less than five (5) years was randomly selected per household using a computer software for anthropometric assessment, hematological and malaria parasitaemia.

Household ownership of ITNs and other household characteristics were assessed using a pre-tested structured questionnaire which were administered by trained fieldworkers. The quality of the ITNs was assessed by direct observation for holes.

Malaria parasitaemia was determined by collecting finger prick blood samples from participants to prepare thick and thin blood smears. The smears were stained with $10 \%$ Giemsa and air-dried. They were examined under the microscope using $\times 10$ eyepieces and $\times 100$ objective. Malaria parasites were counted against 200 white blood slides on the thick smear. A slide was declared negative only after 200 oil immersion fields of the thick smear had been examined. Parasites were expressed per microlitre, assuming a total white cell count of 8,000 per microlitre. Species identification was done using the thin smear. A sub-sample (10\%) of the blood slides were randomly selected and sent to an independent expert microscopists for examination and the results compared with $>90 \%$ concordance. 


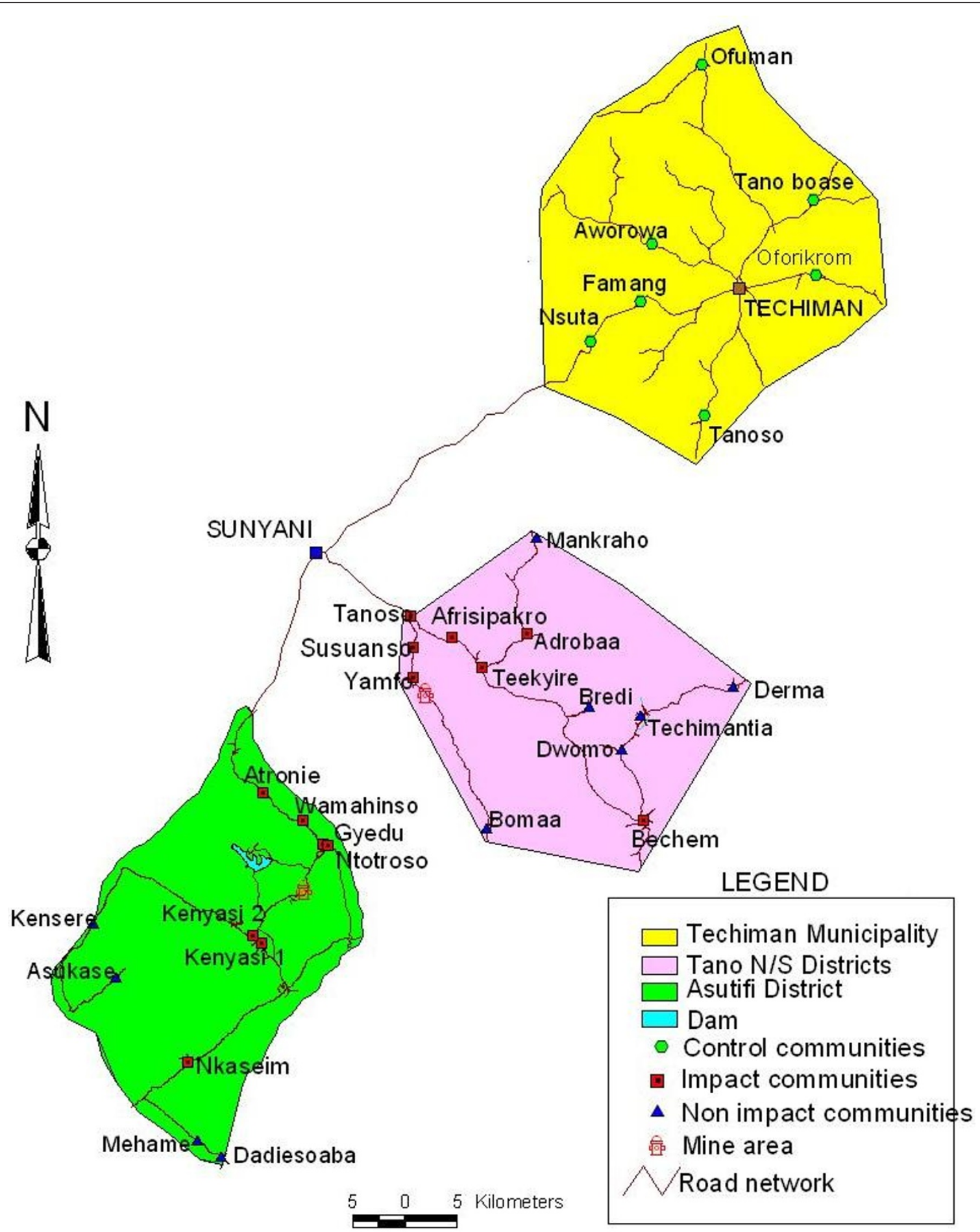

Figure 1 Study area map.

Part of the blood from the finger prick was collected into Hemocue microcuvettes and haemoglobin levels were determined using a calibrated hemocue (HemoCue $\mathrm{GmbH}$, Germany). All children found to be unwell, parasitaemic or anaemia during the survey were referred to a study clinician and treated.

Entomological surveys were carried out in the Asutifi and the Tano N/S districts from November 2006 to 
August 2007. The dry season period (Nov. 2006 - Feb. 2007) and wet season period (May 2007 - Aug. 2007) were purposefully planned to compare transmission with or without the influence of rainfall in a mining area. No entomology work was carried out in the Techiman district as similar studies were carried out in the Kintampo district, an adjacent district with similar rainfall pattern in 2004 [3]. Centre for Disease Control (CDC) light trap catches were performed concurrently on each night of mosquito collection in both impact and non-impact communities. Index persons were randomly selected from the Asutifi/Tano household enumeration database. A total of about 1,100 possible compounds were randomly selected from enumerated households in the Asutifi and Tano N/S districts to receive mosquito $C D C$ light traps. The house of the "index" person was the house of choice to set traps. Traps were hung at the foot end adjacent to the "index" net of the "index" person. Untreated mosquito nets were provided to household members whose rooms were used on the night of trap setting to ensure they were protected while ensuring that mosquitos were not repelled. This method was approved by ethics committees. Four traps were set weekly and mosquitoes collected were chloroformed and morphologically identified using Anopheline morphological identification keys [10]. They were stored in $1.5 \mathrm{ml}$ eppendorf tubes and transported on weekly basis to the Kintampo Health Research Centre laboratories for ELISA as per the procedures of Wirtz et al [11]. An average cut-off point of $0.2 \mathrm{~nm}$ absorbance wavelength was considered positive. Positive samples were re-tested and PCR analysis performed as described [11-13]. The entomologic inoculation rate (EIR) was calculated as the product of the proportion of Anopheles positive by ELISA also termed as sporozoite rate (SR) and the Human Biting Rate which is estimated as the geometric mean of Anopheles caught per CDC light traps set.

\section{Identification of Anopheles gambiae s.I}

A total of 200 morphologically identified Anopheles gambiae s.l. specimens were further analysed by polymerase chain reaction (PCR) in order to establish members of the species complex and molecular forms composition [14].

\section{Data management and statistical analysis}

All data collected in the field or the laboratory were logged for traceability, and then batched for double data entry and processing using Microsoft ${ }^{\circledR}$ Visual FoxPro 6.0. All data management processes were done at the computer laboratory of the Kintampo Health Research Centre. Data analysis was done using StataCorp Stata 10, TX USA. Averages and proportions were used to provide descriptions of age- and parasite prevalence, density, infection rates and the proportions of parasite clones that persisted during the survey. Socio-economic status was calculated for each household using World Bank asset scores for Ghana, based on ownership of a television, radio, refrigerator, car, motorcycle, bicycle, farm, electricity in house, ceiling, floor cover, and number of individuals/sleeping room. The anthropometric indices height-for-age (HA), weight-for-age (WA), weight-for-height (WH), were expressed as Z-scores using the WHO Anthro for personal computers, Version 3.1, 2010: Software for assessing growth and development of the world's children. A child was identified as being malnourished if $\mathrm{s} /$ he scored $<-2$ in one of the HA, WA, or WH indices.

Malaria parasitaemia, anaemia (haemoglobin $<10 \mathrm{~g} /$ $\mathrm{dL}$ ) and ITN usage were the main outcome variables. Odds ratios were calculated with their 95\% confidence interval to assess the relationships between exposure and outcome variables using univariate and multivariate logistic regression models. The Wald's test and likelihood ratio test were used to estimate $\mathrm{P}$ values for exposure variables with two (2) levels and more than two (2) levels respectively in both the univariate and multivariate logistic regression models. $\mathrm{P}$ values less than 0.05 were considered statistically significant. Missing values were not included in the logistic regression models.

\section{Ethical approval}

Ethical approval to conduct the study was granted by the Kintampo Health Research Centre Institutional Ethics Committee. Community entry involved explaining the study to key community opinion leaders followed by community durbars/meetings. At these meetings, the study's aims, objectives, risk and benefits were explained to all participants. A signed/thumb printed written consent was obtained from each respondent. All data collected are kept confidential.

\section{Results}

\section{Household characteristics}

A total of 1,671 households with a child less than five years were selected. Response rate was approximately $100 \%$. About $50 \%$ of the household heads were males (Table 1).

Majority of household heads were between ages 30-39 years $(27.8 \%)$ and $40-49$ years (27.3). Majority of children (63.6\%; 95\% CI 61.2 - 65.9) in the households were $\geq 24$ months. Health insurance coverage was $42.3 \%$, (95\% CI 40.5 - 45.3).

\section{Malaria parasitaemia}

A total of 1,671 children less than five years were surveyed for malaria parasitaemia and anaemia. The 
Table 1 Household characteristics $(N=1671)$

\begin{tabular}{|c|c|c|}
\hline & $\mathrm{n}$ & $\%$ \\
\hline \multicolumn{3}{|l|}{ Gender of household head } \\
\hline Male & 840 & 50.3 \\
\hline Female & 818 & 49.0 \\
\hline Missing & 13 & 0.8 \\
\hline \multicolumn{3}{|l|}{ Age group of household head } \\
\hline $15-29$ & 182 & 10.9 \\
\hline $30-39$ & 454 & 27.2 \\
\hline $40-49$ & 445 & 26.6 \\
\hline $50-59$ & 229 & 13.7 \\
\hline $60+$ & 321 & 19.2 \\
\hline Missing & 40 & 2.4 \\
\hline \multicolumn{3}{|l|}{ Child age } \\
\hline$<24$ months & 609 & 36.4 \\
\hline$\geq 24$ months & 1062 & 63.6 \\
\hline \multicolumn{3}{|l|}{ Household head educational level } \\
\hline None & 603 & 36.1 \\
\hline Primary & 203 & 12.2 \\
\hline Middle/JHS & 645 & 38.6 \\
\hline$>$ middle/JHS & 208 & 12.5 \\
\hline Missing & 12 & 0.7 \\
\hline \multicolumn{3}{|l|}{ Household socioeconomic status } \\
\hline Poorest & 357 & 21.4 \\
\hline Second & 333 & 19.9 \\
\hline Third & 341 & 20.4 \\
\hline Fourth & 333 & 19.9 \\
\hline Least poor & 300 & 18.0 \\
\hline Missing & 7 & 0.4 \\
\hline \multicolumn{3}{|l|}{ Health Insurance membership } \\
\hline No & 950 & 56.9 \\
\hline Yes & 714 & 42.7 \\
\hline Missing & 7 & 0.4 \\
\hline \multicolumn{3}{|l|}{ Household size } \\
\hline$\leq 6$ & 712 & 42.6 \\
\hline$>6$ & 952 & 57.0 \\
\hline Missing & 7 & 0.4 \\
\hline \multicolumn{3}{|l|}{ Area of residence } \\
\hline Asutifi impact & 246 & 14.7 \\
\hline Asutifi non impact & 150 & 9.0 \\
\hline Tano N/S impact & 580 & 34.7 \\
\hline Tano N/S non impact & 360 & 21.5 \\
\hline Techiman & 328 & 19.6 \\
\hline Missing & 7 & 0.4 \\
\hline
\end{tabular}

JHS-Junior High School prevalence of any malaria parasitaemia was $22.8 \%$ (95\% CI 20.8 - 24.9). Plasmodium falciparum constituted 98.1\% (95\% CI 96.2 - 99.2) of parasitaemia. Plasmodium malariae was uncommon -1.9\% (95\% CI 0.81 - 3.8); no Plasmodium ovale or Plasmodium vivax was identified; there were no mixed infections. The geometric mean $P$. falciparum asexual parasite count was 1602 (95\% CI 1,140 - 2,252) and 1,195 (95\% CI 985 - 1,449) among children $<24$ months and $\geq 24$ months respectively. The proportion of children with parasite counts at various cut-off points was similar among the two age groups (Figure 2). Majority of the children $(<24$ months: $74 \%$, 95\% CI 64.4 - 82.9; $\geq 24$ months: $82.9 \%$, 95\% CI 76.7 - 86.1) had low parasite counts $<5,000 / \mu \mathrm{L}$. A univariate logistic regression model analysis was fit prior to multivariate regression models. Malaria parasitaemia was significantly associated with the socioeconomic quintile $(\mathrm{p}<0.001)$ with the strength of the association decreasing along the better socioeconomic quintiles. The least poor were significantly less likely to have malaria parasitaemia compared to the poor, OR 0.40 (95\% CI 0.27 - 0.60) (Table 2). Health insurance membership protected against malaria parasitaemia (OR $0.51,95 \%$ CI $0.40-0.66, \mathrm{p}<0.001)$. Household ITN ownership was weakly associated with malaria parasitaemia (OR 0.80, 95\% CI $0.62-1.03, \mathrm{p}=0.08$ ). Children $\geq$ 24 months were significantly more likely to have parasitaemia compared to children $<24$ months (OR 1.95, $95 \%$ CI $1.50-2.53, \mathrm{p}<0.001$ ) (Table 3 ). In the multivariate logistic regression model, there were strong evidence of associations between malaria parasitaemia and

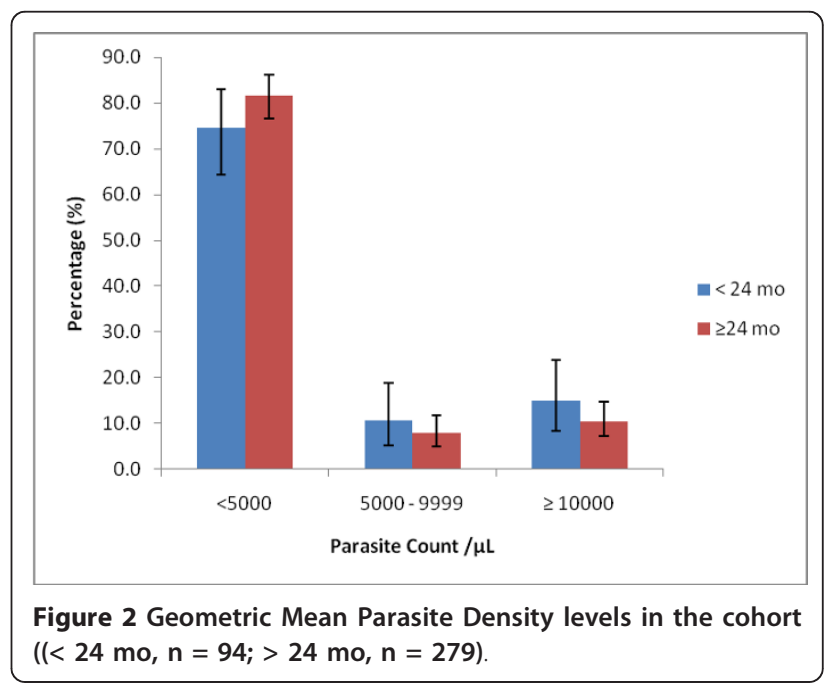


Table 2 Analysis of household attributes associated with malaria parasitaemia

\begin{tabular}{|c|c|c|c|c|c|}
\hline Attribute & $\mathrm{n} / \mathrm{N}(\%)$ & $\mathrm{OR}^{\beta},(95 \% \mathrm{Cl})$ & $\mathrm{p}$ & $\mathrm{OR}^{\gamma},(95 \% \mathrm{Cl})$ & $\mathbf{p}$ \\
\hline & & Unadjusted & & Adjusted & \\
\hline \multicolumn{6}{|c|}{ Gender of household head } \\
\hline Female & 176/796 (22.1) & 1 & - & 1 & - \\
\hline Male & $188 / 827(22.7)$ & $1.04(0.82-1.31)$ & 0.764 & $0.99(0.77-1.27)$ & 0.954 \\
\hline \multicolumn{6}{|c|}{ Age group of household head } \\
\hline $15-29$ & $39 / 180(21.7)$ & 1 & - & 1 & - \\
\hline $30-39$ & 74/447 (16.6) & $0.71(0.46-1.10)$ & $0.003^{*}$ & $0.75(0.47-1.20)$ & $0.042^{*}$ \\
\hline $40-49$ & $107 / 428(25.0)$ & $1.21(0.79-1.83)$ & & $1.26(0.79-2.03)$ & \\
\hline $50-59$ & $65 / 225(28.9)$ & $1.47(0.93-2.32)$ & & $1.38(0.82-2.34)$ & \\
\hline $60+$ & $71 / 317(22.4)$ & $1.04(0.67-1.62)$ & & $1.12(0.66-1.91)$ & \\
\hline \multicolumn{6}{|c|}{ Household head educational level } \\
\hline None & $164 / 586(28.0)$ & 1 & - & 1 & - \\
\hline Primary & $42 / 200(21.0)$ & $0.68(0.47-1.01)$ & $<0.001^{*}$ & $0.78(0.51-1.18)$ & $0.499^{*}$ \\
\hline Middle/JHS & 125/631 (19.8) & $0.64(0.49-0.83)$ & & $0.80(0.58-1.10)$ & \\
\hline$>$ middle/JHS & $31 / 207(15.0)$ & $0.45(0.30-0.69)$ & & $0.86(0.52-1.41)$ & \\
\hline \multicolumn{6}{|c|}{ Household socioeconomic status } \\
\hline Poorest & $103 / 348(29.6)$ & 1 & - & 1 & - \\
\hline Second & $81 / 323(25.1)$ & $0.80(0.57-1.12)$ & $<0.001^{*}$ & $0.88(0.60-1.27)$ & $0.047^{*}$ \\
\hline Third & $83 / 334(24.9)$ & $0.79(0.56-1.1)$ & & $0.91(0.61-1.34)$ & \\
\hline Fourth & $52 / 327(15.9)$ & $0.45(0.31-0.65)$ & & $0.59(0.38-0.92)$ & \\
\hline Least poor & $43 / 296(14.5)$ & $0.40(0.27-0.60)$ & & $0.56(0.35-0.91)$ & \\
\hline \multicolumn{6}{|c|}{ Member of Health Insurance } \\
\hline$\overline{\text { No }}$ & 250/927 (27.0) & 1 & - & 1 & - \\
\hline Yes & 112/701 (16.0) & $0.51(0.40-0.66)$ & $<0.001$ & $0.60(0.45-0.80)$ & 0.001 \\
\hline \multicolumn{6}{|c|}{ Household ITN ownership } \\
\hline$\overline{\mathrm{No}}$ & $124 / 498(24.9)$ & 1 & - & 1 & - \\
\hline Yes & 232/1107 (21.0) & $0.80(0.62-1.03)$ & 0.079 & $0.81(0.62-1.07)$ & 0.147 \\
\hline \multicolumn{6}{|l|}{ Household size } \\
\hline$\leq 6$ & 130/696 (18.7) & 1 & - & 1 & - \\
\hline$>6$ & 232/932 (24.9) & $1.44(1.13-1.84)$ & 0.003 & $1.15(0.85-1.54)$ & 0.364 \\
\hline \multicolumn{6}{|l|}{ Area of residence } \\
\hline Asutifi impact & $50 / 236(21.2)$ & 1 & - & 1 & - \\
\hline Asutifi non impact & $34 / 148(23.0)$ & $1.11(0.68-1.82)$ & $<0.001^{*}$ & $0.85(0.49-1.47)$ & $0.065^{*}$ \\
\hline Tano N/S impact & $94 / 575(16.4)$ & $0.73(0.50-1.07)$ & & $0.92(0.60-1.40)$ & \\
\hline Tano N/S non impact & $103 / 358(28.8)$ & $1.50(1.02-2.21)$ & & $1.43(0.93-2.20)$ & \\
\hline Techiman & $81 / 311(26.1)$ & $1.31(0.88-2.0)$ & & $1.27(0.79-2.02)$ & \\
\hline
\end{tabular}

$\beta$-Univariate logistic regression odds ratio (OR); $\gamma$-multivariate logistic regression odds ratio (OR); Cl-confidence interval; * -Likelihood ratio $\mathrm{p}$-values; JHS-Junior High School

household membership with health insurance $(\mathrm{p}=$ $0.001)$; child age $(\mathrm{p}<0.001)$ and anaemia $(\mathrm{p}<0.001)$.

\section{Anaemia}

The prevalence of anaemia (haemoglobin $<10 \mathrm{~g} / \mathrm{dL}$ ) among all children $<5$ years was $30.5 \%$ (95\% CI 28.2 32.8). The prevalence of anaemia was high among children $<24$ months compared to children $\geq 24$ months 44.1\% (95\% CI 40.0 - 48.3) and $23.8 \%$ (95\% CI 21.2 26.5) respectively. About 32.7\% (95\% CI 28.9 - 36.7) of the children $<24$ months and $19.0 \%$ (95\% CI 16.6 21.5) of children $>=24$ months had haemoglobin levels between $8.0-9.9 \mathrm{~g} / \mathrm{dL}$ (Figure 3).

In the univariate logistic regression model, children living in households with a male as a household head were significantly more likely to be anaemic compared to children living in households with females as household heads (OR 1.30; 95\% CI $1.05-1.60, \mathrm{p}=0.016$ ); childhood anaemia was less likely among household 
Table 3 Analysis of child attributes associated with malaria parasitaemia

\begin{tabular}{|c|c|c|c|c|c|}
\hline Attribute & $\mathrm{n} / \mathrm{N}(\%)$ & $\mathrm{OR}^{\beta},(95 \% \mathrm{Cl})$ & $\mathbf{p}$ & $\mathrm{OR}^{\gamma},(95 \% \mathrm{Cl})$ & $\mathrm{p}$ \\
\hline & & Unadjusted & & Adjusted & \\
\hline \multicolumn{6}{|l|}{ Child age } \\
\hline$<24$ months & $93 / 600(15.5)$ & 1 & - & 1 & - \\
\hline$\geq 24$ months & 273/1035 (26.4) & $1.95(1.50-2.53)$ & $<0.001$ & $2.44(1.79,3.34)$ & $<0.001$ \\
\hline \multicolumn{6}{|c|}{ Height for age z-score } \\
\hline Normal & $302 / 1403(21.5)$ & 1 & - & 1 & - \\
\hline Abnormal & $59 / 209(28.2)$ & $1.43(1.03-1.99)$ & 0.031 & $1.17(0.79-1.73)$ & 0.442 \\
\hline \multicolumn{6}{|c|}{ Weight for age z-score } \\
\hline Normal & $333 / 1519(21.9)$ & 1 & - & 1 & - \\
\hline Abnormal & 30/98 (30.6) & $1.57(1.01-2.46)$ & 0.047 & $1.54(0.84-2.85)$ & 0.166 \\
\hline \multicolumn{6}{|c|}{ Weight for height z-score } \\
\hline Normal & $340 / 1500(22.7)$ & 1 & - & 1 & - \\
\hline Abnormal & 18/104 (17.3) & $0.71(0.42-1.20)$ & 0.206 & $0.56(0.30-1.05)$ & 0.071 \\
\hline \multicolumn{6}{|l|}{ Anaemia } \\
\hline Non-anaemic & $216 / 1130(19.1)$ & 1 & - & 1 & - \\
\hline Anaemic & $150 / 505(29.7)$ & $1.79(1.40-2.28)$ & $<0.001$ & $1.70(1.30-2.22)$ & $<0.001$ \\
\hline
\end{tabular}

$\beta$-Univariate logistic regression odds ratio $(\mathrm{OR}) ; \gamma$-multivariate logistic regression odds ratio (OR); Cl-confidence interval

heads with characteristics, such as educational level > middle/Junior high school (OR 0.61; 95\% CI 0.43 - 0.87, $\mathrm{p}=0.029$ ), the least poor socioeconomic status (OR $0.5795 \%$ CI $0.40-0.80, \mathrm{p}=0.001)$ and household ITN ownership (OR 0.75 95\% CI 0.61-0.93, p = 0.010). There was however no significant association between childhood anaemia and household health insurance membership or household size (Table 4). Children $\geq 24$ months were significantly less likely to be anaemic compared to children < 24 months (OR 0.41 95\% CI 0.33-0.51, p < 0.001) (Table 5). Attributes such as sex and age of household head, area of residence and child age remain significant in their relationship with anaemia in the multivariate logistic regression model.

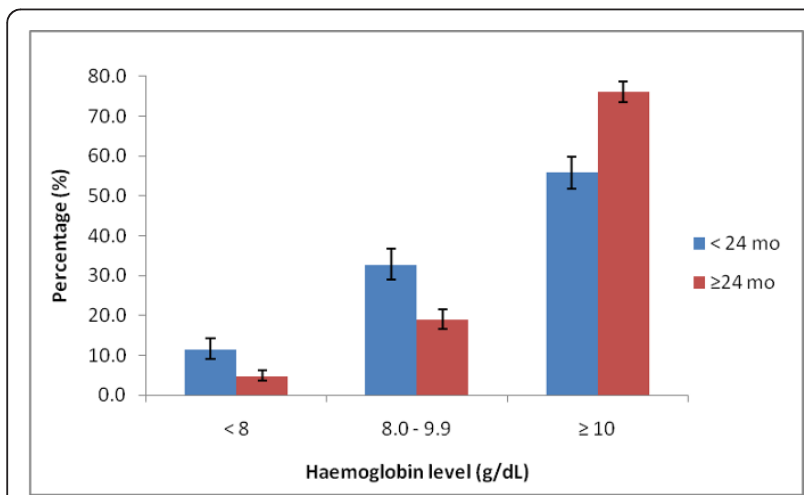

Figure 3 Haemoglobin levels in the cohort of children $(<24$ mo, $\mathrm{n}=585 ;>24 \mathrm{mo}, \mathrm{n}=1035$ ).

\section{ITN ownership}

About $68.7 \%$ (95\% CI 66.3 - 70.9) of households own at least one ITN. The median ITN per household was 2 (range 1 - 7). About 18.1\% (95\% CI 15.9 - 20.5) of ITNs observed for quality had holes in them. About $86.4 \%$ (95\% CI 84.3 - 88.4) of household that owned ITNs had at least one person sleeping under an ITN the night before the interview. Majority of ITNs (64.9\%, 95\% CI 62.1 - 67.7) were obtained free of charge as part of a national campaign while $26.4 \%$ (95\% CI 23.8 - 29.0) bought their ITNs on the open market at commercial prices. There was no significant association between household ITN ownership and household head characteristics such as sex and educational level in the univariate logistic regression model (Table 6). There was however a significant association between ITN ownership and attributes such as health insurance membership and area of residence that remained significant in the multivariate logistic regression models. Households with children $\geq 24$ months were significantly less likely to own an ITN (Table 7)

\section{Mosquito abundance and entomological inoculation rates (EIRs)}

A total of 5,257 mosquitoes were caught from 818 light traps set; Anopheles gambiae comprised of $64.1 \%$ ( $\mathrm{n}=$ 3,371 ) of the mosquitoes caught, Anopheles funestus $4.3 \%(\mathrm{n}=227)$ and non-Anopheles species $31.6 \%(\mathrm{n}=$ 1,659) which were predominantly Culex and Aedes species of mosquitoes. A few Mansonia species were recorded in Asutifi (4) and Tano N/S districts (2). 
Table 4 Analysis of household attributes associated with anaemia

\begin{tabular}{|c|c|c|c|c|c|}
\hline Attribute & $\mathrm{n} / \mathrm{N}(\%)$ & $\mathrm{OR}^{\beta},(95 \% \mathrm{Cl})$ & $\mathbf{p}$ & $\mathrm{OR}^{\gamma},(95 \% \mathrm{Cl})$ & $\mathbf{p}$ \\
\hline & & Unadjusted & & Adjusted & \\
\hline \multicolumn{6}{|c|}{ Gender of household head } \\
\hline Female & $226 / 818(27.6)$ & 1 & - & 1 & - \\
\hline Male & $278 / 840(33.1)$ & $1.30(1.05-1.60)$ & 0.016 & $1.28(1.01-1.61)$ & 0.038 \\
\hline \multicolumn{6}{|c|}{ Age group of household head } \\
\hline $15-29$ & 78/182 (42.9) & 1 & - & 1 & - \\
\hline $30-39$ & $122 / 454(26.9)$ & $0.49(0.34-0.70)$ & $0.001^{*}$ & $0.55(0.37-0.82)$ & $0.024^{*}$ \\
\hline $40-49$ & $120 / 445(27.0)$ & $0.49(0.34-0.71)$ & & $0.56(0.37-0.86)$ & \\
\hline $50-59$ & 78/229 (34.1) & $0.69(0.46-1.03)$ & & $0.64(0.40-1.03)$ & \\
\hline $60+$ & 97/321 (30.2) & $0.58(0.40-0.84)$ & & $0.49(0.31-0.80)$ & \\
\hline \multicolumn{6}{|c|}{ Household head educational level } \\
\hline None & 206/603 (34.2) & 1 & - & 1 & - \\
\hline Primary & $63 / 203(31.0)$ & $0.87(0.62-1.22)$ & $0.029^{*}$ & $0.72(0.49-1.06)$ & $0.080^{*}$ \\
\hline Middle/JHS & $185 / 645(28.7)$ & $0.78(0.61-0.98)$ & & $0.70(0.52-0.95)$ & \\
\hline$>$ middle/JHS & $50 / 208(24.0)$ & $0.61(0.43-0.87)$ & & $0.84(0.40-0.99)$ & \\
\hline \multicolumn{6}{|c|}{ Household socioeconomic status } \\
\hline Poorest & 123/357 (34.5) & 1 & - & 1 & - \\
\hline Second & $120 / 333(36.0)$ & $1.07(0.78-1.47)$ & $0.001^{*}$ & $1.17(0.82-1.68)$ & $0.191^{*}$ \\
\hline Third & $92 / 341(27.0)$ & $0.70(0.51-0.97)$ & & $0.83(0.57-1.22)$ & \\
\hline Fourth & 102/333 (30.6) & $0.84(0.61-1.16)$ & & $0.99(0.67-1.46)$ & \\
\hline Least poor & $69 / 300(23.0)$ & $0.57(0.40-0.80)$ & & $0.74(0.48-1.14)$ & \\
\hline \multicolumn{6}{|c|}{ Member of Health Insurance } \\
\hline No & 250/927 (27.0) & 1 & - & 1 & - \\
\hline Yes & $112 / 701(16.0)$ & $0.51(0.40-0.66)$ & 0.010 & $1.00(0.77-1.30)$ & 0.971 \\
\hline \multicolumn{6}{|c|}{ Household ITN ownership } \\
\hline$\overline{\mathrm{No}}$ & $313 / 950(33.0)$ & 1 & - & 1 & - \\
\hline Yes & 193/714 (27.0) & $0.75(0.61-0.93)$ & 0.010 & $0.91(0.69-1.20)$ & 0.514 \\
\hline \multicolumn{6}{|l|}{ Household size } \\
\hline$\leq 6$ & $201 / 712(28.2)$ & 1 & - & 1 & - \\
\hline$>6$ & $305 / 952(32.0)$ & $1.20(0.97-1.48)$ & 0.095 & $1.28(0.97-1.68)$ & 0.080 \\
\hline \multicolumn{6}{|l|}{ Area of residence } \\
\hline Asutifi impact & 84/246 (34.2) & 1 & - & 1 & - \\
\hline Asutifi non impact & $86 / 150$ (57.3) & $2.59(1.71-3.93)$ & $<0.001^{*}$ & $2.22(1.38-3.55)$ & $<0.001^{*}$ \\
\hline Tano N/S impact & 115/580 (19.8) & $0.48(0.34-0.67)$ & & $0.47(0.32-0.68)$ & \\
\hline Tano N/S non impact & 139/360 (38.6) & $1.21(0.86-1.70)$ & & $0.97(0.66-1.43)$ & \\
\hline Techiman & $82 / 328(25.0)$ & $0.64(0.45-0.92)$ & & $0.49(0.32-0.75)$ & \\
\hline
\end{tabular}

$\beta$-Univariate logistic regression odds ratio (OR); $\gamma$-multivariate logistic regression odds ratio (OR); Cl-confidence interval; * -Likelihood ratio $\mathrm{p}$-values; JHS-Junior High School

EIRs for both Anopheles gambiae and Anopheles funestus were generally high. In the impact and nonimpact areas of the Asutifi district, the median EIR was $46 \mathrm{ib} / \mathrm{p} / \mathrm{m}$ (range $0-826 \mathrm{ib} / \mathrm{p} / \mathrm{m}$ ) and $51 \mathrm{ib} / \mathrm{p} / \mathrm{m}(0-216)$ in the impact and non impact areas respectively. The highest was recorded in June 2007 at both impact and non impact areas respectively (Figure 4). EIRs in Tano $\mathrm{N} / \mathrm{S}$ districts were also high, median $65 \mathrm{ib} / \mathrm{p} / \mathrm{m}$ (range
$48-219 \mathrm{ib} / \mathrm{p} / \mathrm{m}$ ) and 102 (range $14-669 \mathrm{ib} / \mathrm{p} / \mathrm{m}$ ) in the impact and non-impact area respectively with the highest in May 2007 (Figure 5).

The EIR of Anopheles gambiae were generally higher than Anopheles funestus. In Tano N/S alone, the median EIR for Anopheles gambiae alone was $73 \mathrm{ib} / \mathrm{p} / \mathrm{m}$ (range: 39 - $438 \mathrm{ib} / \mathrm{p} / \mathrm{m})$ compared to Anopheles funestus median $0 \mathrm{ib} / \mathrm{p} / \mathrm{m}$ (range $0-5 \mathrm{ib} / \mathrm{p} / \mathrm{m}$ ) alone (Figure 6). 
Table 5 Analysis of child attributes associated with anaemia

\begin{tabular}{|c|c|c|c|c|c|}
\hline Attribute & $\mathrm{n} / \mathrm{N}(\%)$ & $\mathrm{OR}^{\beta},(95 \% \mathrm{Cl})$ & $p$ & $\mathrm{OR}^{\gamma},(95 \% \mathrm{Cl})$ & $\mathrm{p}$ \\
\hline & & Unadjusted & & Adjusted & \\
\hline \multicolumn{6}{|l|}{ Child age } \\
\hline$<24$ months & $259 / 609(42.5)$ & 1 & - & 1 & - \\
\hline$\geq 24$ months & 247/1062 (23.3) & $0.41(0.33-0.51)$ & $<0.001$ & $0.32(0.25,0.42)$ & $<0.001$ \\
\hline \multicolumn{6}{|c|}{ Height for age z-score } \\
\hline Normal & $424 / 1429(29.7)$ & 1 & - & 1 & - \\
\hline Abnormal & $76 / 211(26.0)$ & $1.33(0.99-1.81)$ & 0.062 & $1.62(1.11-2.37)$ & 0.012 \\
\hline \multicolumn{6}{|c|}{ Weight for age z-score } \\
\hline Normal & $457 / 1550(29.5)$ & 1 & - & 1 & - \\
\hline Abnormal & 43/99 (43.4) & $1.84(1.22-2.77)$ & 0.004 & $1.52(0.86-2.68)$ & 0.147 \\
\hline \multicolumn{6}{|c|}{ Weight for height z-score } \\
\hline Normal & $456 / 1523(29.9)$ & 1 & - & 1 & - \\
\hline Abnormal & $41 / 105(39.1)$ & $1.50(0.99-2.25)$ & 0.051 & $1.17(0.70-1.98)$ & 0.546 \\
\hline
\end{tabular}

$\beta$-Univariate logistic regression odds ratio $(\mathrm{OR}) ; \gamma$-multivariate logistic regression odds ratio (OR); $\mathrm{Cl}$-confidence interval

\section{Polymerase chain reaction analysis}

Mosquitoes randomly selected and amplified by PCR were all An. gambiae sensu-stricto as confirmed by the size of the amplified DNA fragment of 390 base pairs. One hundred out of the 200 mosquitoes identified as An. gambiae s.s. were randomly selected for the identification to the molecular form by enzyme digestion with Hha1. All 100 mosquitoes were S-forms shown by restriction analysis.

Two hundred mosquitoes were randomly selected to determine knockdown resistance $(k d r)$ mutations. One hundred and ninety three out of the 200 selected mosquitoes $(97 \%)$ possessed the $k d r$ mutation $(k d r+)$, whilst seven $(3 \%)$ did not $(k d r-)$.

\section{Discussion}

The study assessed the epidemiology of malaria in a rural forest area of the Brong Ahafo region in Ghana. The prevalence of malaria parasitaemia and anaemia among children less than five years and malaria entomology were determined. Though renewed efforts in controlling malaria in sub-Saharan Africa has led to reports of decline in the burden of malaria in some parts of Africa [4-7,9], there is little evidence in Ghana to suggest a decline in out-patient attendance due to malaria and malaria mortality amidst the intensified delivery of malaria control interventions [2]. In this survey, a malaria epidemiology survey in a forest area of Ghana including a mining area was conducted to plan malaria control programmes in these areas.

The prevalence of $P$. falciparum among children gives an estimation of the burden of malaria in a particular area. In the study area, the prevalence of malaria parasitaemia was relatively low $22.8 \%$ (95\% CI 20.8 - 24.9) compared to reports from other rural parts of Ghana;
$58 \%$ in a forest savanna transitional area of Kintampo in 2004 [3]; between 55.5 - 69.3\% in savanna area in northern Ghana between 2000 and 2002 [15,16]. The prevalence of malaria parasitaemia in the area was however comparable to reports in urban semi-humid areas $12.8 \%-37.8 \%$ in 2005 [17].

The relationship between malnutrition and malaria are inconsistent in the literature. Studies conducted in Ethiopia [18] and southern Ghana[19] showed no evidence of relation between malnutrition and anaemia contrary to studies conducted in urban Equatorial Guinea [20], in western Kenya [21] and reviews by Caulfield et al [22] that suggest a strong relationship between malnutrition and malaria. In this study, there was no association of malaria parasitaemia with malnutrition.

In 2003, the government of Ghana introduced the National Health Insurance Scheme with the aim of reducing financial constraints as a gap in accessing health. Household membership of the insurance scheme provides children to seek health in health facilities closest to them. Common illnesses, such as malaria, are treated without direct cash payment at the point of service. In this study, health insurance membership was protective against malaria parasitaemia but had no significant relationship with anaemia. Participants who subscribe to the health insurance may regularly seek health care and may have been treated for malaria thus, the observed protection of malaria parasitaemia by health insurance membership.

ITNs are known to prevent malaria infection by reducing human contact with the malaria vector and thus able to reduce all-cause mortality in children less than five years old by $17 \%$ in northern Ghana [23] and about $44 \%$ in Kenya [24]. ITN ownership has increased in recent times due to the support of local government 
Table 6 Analysis of household attributes associated with household ITN ownership

\begin{tabular}{|c|c|c|c|c|c|}
\hline Attribute & $\mathrm{n} / \mathrm{N}(\%)$ & $\mathrm{OR}^{\beta},(95 \% \mathrm{Cl})$ & $\mathbf{p}$ & $\mathrm{OR}^{\gamma},(95 \% \mathrm{Cl})$ & $\mathbf{p}$ \\
\hline & & Unadjusted & & Adjusted & \\
\hline \multicolumn{6}{|c|}{ Gender of household head } \\
\hline Female & $561 / 804(69.8)$ & 1 & - & 1 & - \\
\hline Male & $555 / 823(67.4)$ & $0.90(0.73-1.11)$ & 0.309 & $0.88(0.70-1.10)$ & 0.271 \\
\hline \multicolumn{6}{|c|}{ Age group of household head } \\
\hline $15-29$ & 127/180 (70.6) & 1 & - & 1 & - \\
\hline $30-39$ & $327 / 446(73.3)$ & $1.15(0.78-1.68)$ & $0.018^{*}$ & $1.06(0.70-1.60)$ & $<0.001^{*}$ \\
\hline $40-49$ & $303 / 439(69.0)$ & $0.93(0.64-1.36)$ & & $0.69(0.45-1.06)$ & \\
\hline $50-59$ & 140/227 (61.7) & $0.67(0.44-1.02)$ & & $0.43(0.27-0.70)$ & \\
\hline $60+$ & 205/316 (64.9) & $0.77(0.52-1.14)$ & & $0.47(0.29-0.77)$ & \\
\hline \multicolumn{6}{|c|}{ Household head educational level } \\
\hline None & $406 / 593(68.5)$ & 1 & - & 1 & - \\
\hline Primary & $132 / 203(65.0)$ & $0.86(0.61-1.20)$ & $0.131^{*}$ & $0.91(0.62-1.32)$ & $0.402^{*}$ \\
\hline Middle/JHS & $433 / 637(68.0)$ & $0.98(0.77-1.24)$ & & $0.98(0.73-1.32)$ & \\
\hline$>$ middle/JHS & 152/202 (75.3) & $1.40(0.97-2.01)$ & & $1.35(0.86-2.10)$ & \\
\hline \multicolumn{6}{|c|}{ Household socioeconomic status } \\
\hline Poorest & $237 / 348(68.1)$ & 1 & - & 1 & - \\
\hline Second & $214 / 330(64.9)$ & $0.86(0.63-1.19)$ & $0.013^{*}$ & $1.0(0.70-1.43)$ & $0.148^{*}$ \\
\hline Third & 226/338 (66.9) & $0.95(0.69-1.30)$ & & $0.97(0.67-1.41)$ & \\
\hline Fourth & $223 / 330(67.6)$ & $0.98(0.71-1.35)$ & & $1.05(0.72-1.55)$ & \\
\hline Least poor & $226 / 294(76.9)$ & $1.56(1.09-2.21)$ & & $1.55(1.01-2.38)$ & \\
\hline \multicolumn{6}{|c|}{ Member of Health Insurance } \\
\hline No & 608/937 (64.9) & 1 & - & 1 & - \\
\hline Yes & $518 / 703(73.7)$ & $1.51(1.22-1.88)$ & $<0.001$ & $1.35(1.04-1.74)$ & 0.022 \\
\hline \multicolumn{6}{|l|}{ Household size } \\
\hline$\leq 6$ & 462/697 (66.3) & 1 & - & 1 & - \\
\hline$>6$ & $664 / 943(70.4)$ & $1.21(0.98-1.49)$ & 0.075 & $1.37(1.05-1.79)$ & 0.020 \\
\hline \multicolumn{6}{|l|}{ Area of residence } \\
\hline Asutifi impact & $107 / 246(43.5)$ & 1 & - & 1 & - \\
\hline Asutifi non impact & $80 / 150$ (53.3) & $1.48(0.99-2.23)$ & $<0.001^{*}$ & $1.44(0.91-2.27)$ & $<0.001^{*}$ \\
\hline Tano N/S impact & $423 / 562(75.3)$ & $3.95(2.88-5.43)$ & & $3.55(2.53-4.99)$ & \\
\hline Tano N/S non impact & 268/359 (74.7) & $3.83(2.27-5.41)$ & & $3.90(2.68-5.67)$ & \\
\hline Techiman & $248 / 323(76.8)$ & $4.30(2.99-6.16)$ & & $4.84(3.22-7.26)$ & \\
\hline
\end{tabular}

and international donors such as USAID and their private partners [25]. In 2003, ITN ownership in Ghana was less than $10 \%$ but had increased to about $33 \%$ in 2008 [26]. In this study ITN ownership (at least one) was lowest in the Asutifi area (range 43\% - 53.3\%) compared to $76.8 \%$ in the Techiman area. This difference in household ITN ownership was due to mass distribution of ITNs to all households with children less than two years as part of Child Survival strategies throughout Ghana. The relatively low coverage in Asutifi is because this survey was carried out prior to the free distribution of treated bed-nets in the Child Survival Campaign. The coverage determined in the study area are similar to the coverage of $45.6 \%$ assessed in 2008 for the same area during the Ghana Health and Demographic Survey [26]. The coverage of ITNs could further be increased and maintained at the World Health Organization target of $\geq 80 \%$ if private companies such as Newmont Ghana Gold Limited and other partners could support the Ghana Health Service and the communities with additional ITNs.

Despite the benefits of ITNs in controlling malaria, its patronage has not been quite encouraging and its usage is for some reasons other than for malaria control. For 
Table 7 Analysis of child attributes associated with household ITN ownership

\begin{tabular}{|c|c|c|c|c|c|}
\hline Attribute & $\mathrm{n} / \mathrm{N}(\%)$ & $\mathrm{OR}^{\beta},(95 \% \mathrm{Cl})$ & $\mathbf{p}$ & $\mathrm{OR}^{\gamma},(95 \% \mathrm{Cl})$ & $\mathbf{p}$ \\
\hline & & Unadjusted & & Adjusted & \\
\hline \multicolumn{6}{|l|}{ Child age } \\
\hline$<24$ months & 491/596 (82.3) & 1 & - & 1 & - \\
\hline$\geq 24$ months & $635 / 1044(60.8)$ & $0.33(0.26-0.42)$ & $<0.001$ & $0.26(0.20-0.35)$ & $<0.001$ \\
\hline \multicolumn{6}{|c|}{ Height for age z-score } \\
\hline Normal & $960 / 1399(68.6)$ & 1 & - & 1 & - \\
\hline Abnormal & $147 / 210(70.0)$ & $1.07(0.78-1.46)$ & 0.687 & $0.98(0.68-1.42)$ & 0.935 \\
\hline \multicolumn{6}{|c|}{ Weight for age z-score } \\
\hline Normal & $1042 / 1519(68.6)$ & 1 & - & 1 & - \\
\hline Abnormal & 71/99 (71.7) & $1.16(0.74-1.82)$ & 0.517 & $0.95(0.53-1.72)$ & 0.877 \\
\hline \multicolumn{6}{|c|}{ Weight for height z-score } \\
\hline Normal & 1028/1494 (68.8) & 1 & - & 1 & - \\
\hline Abnormal & 73/103 (70.9) & $1.10(0.71-1.71)$ & 0.661 & $0.95(0.54-1.57)$ & 0.767 \\
\hline \multicolumn{6}{|l|}{ Anaemia } \\
\hline Non-anaemic & 782/1138 (68.7) & 1 & - & 1 & - \\
\hline Anaemic & $344 / 502(68.5)$ & $0.99(0.79-1.24)$ & 0.939 & $1.24(0.96-1.60)$ & 0.104 \\
\hline
\end{tabular}

$\beta$-Univariate logistic regression odds ratio $(\mathrm{OR}) ; \gamma$-multivariate logistic regression odds ratio (OR); Cl-confidence interval

instance, in Savalou, Benin mosquito nets were often seen as a means of protection against mosquitoes and other biting insects in order to sleep better rather than as a means of preventing malaria [27]. Several reasons including: lack of money or expensive ITN, unavailability of ITN, no provision for nets to fit sleeping space account for the low mosquito net usage. In this study, it was encouraging to note that ITN use was high; about 86.4\% (95\% CI 84.3 - 88.4) of household that owned ITNs had at least one person sleeping under an ITN the night before the interview. This is consistent with the high coverage of ITN use among children in the same area determined in 2008 [26]. Though there was a high ITN ownership and use, there was no evidence of protection against malaria parasitaemia after adjusting for

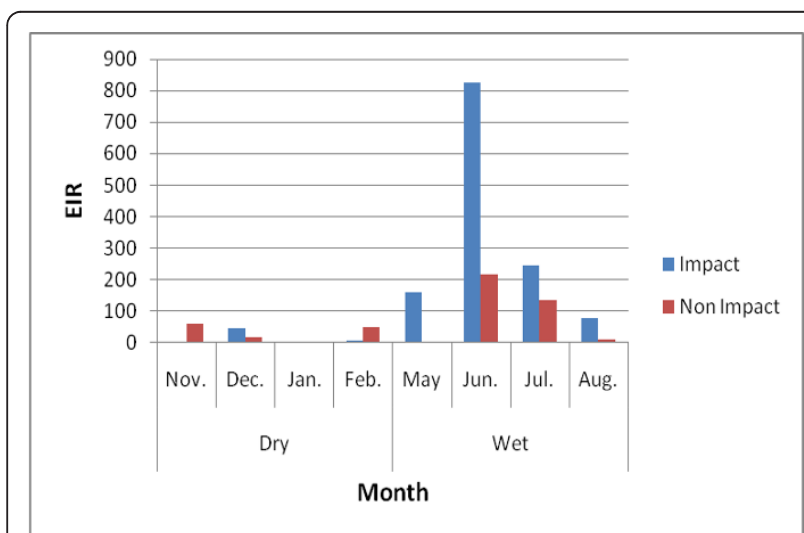

Figure 4 Monthly EIRs in Asutifi district (November 2006August 2007). age, anaemia, malnutrition and other household. This may be due to poor quality of ITNs (about 18\% of household nets had holes) or improper use of ITNs.

One of the commonest causes of anaemia in subSaharan Africa is malaria. In this study, the prevalence of anaemia among all children $<5$ years was moderately high $30.5 \%$ (95\% CI 28.2 - 32.8) with children less than 24 months having a higher risk of anaemia. Although high, it is still lower than reported in other parts of Ghana and follows the same trend as malaria parasitaemia $[3,15,16,28]$. There are other causes of anaemia in children such as malnutrition, hookworm infection, and sickle cell disease but their contribution to anaemia in malaria endemic regions has been found to be minimal compared malaria $[29,30]$. In this study, there was a

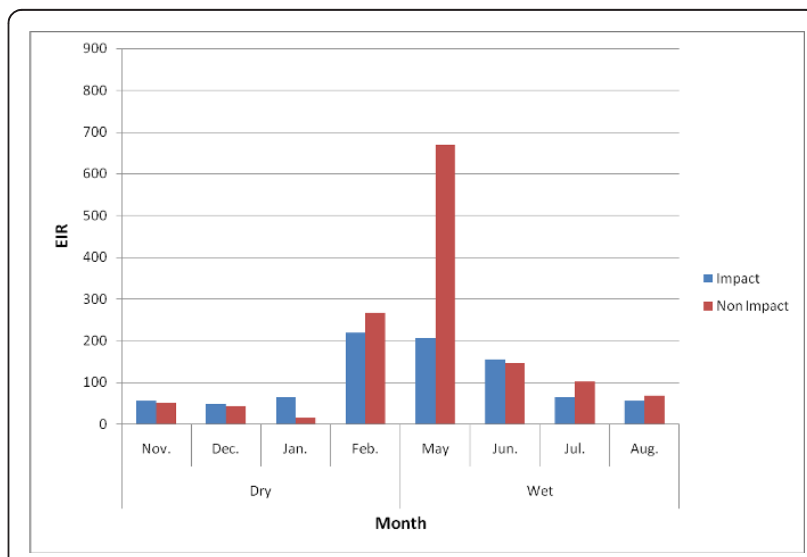

Figure 5 Monthly ElRs in Tano N/S district (November 2006August 2007). 


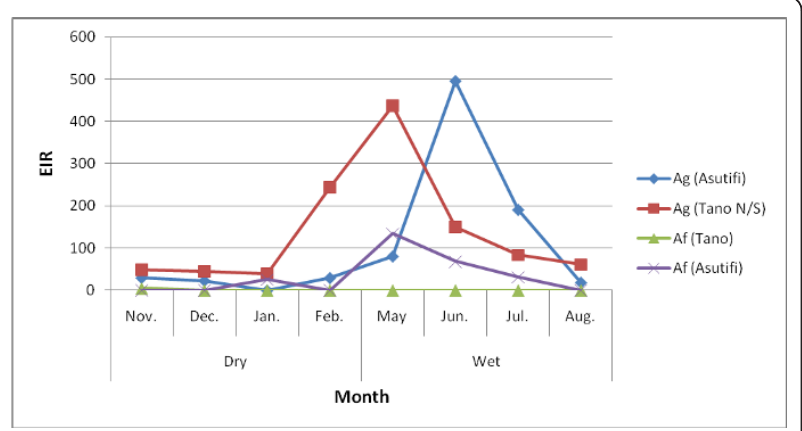

Figure 6 Monthly EIRs by Anopheles gambiae and Anopheles funestus in Asutifi and Tano N/S districts (November 2006August 2007). Ag = Anopheles gambiae. Af = Anopheles funestus (November 2006-August 2007)

weak-association between abnormal height for age scores and anaemia; and a stronger association between malaria parasitaemia and anaemia after adjusting for age, ITN use and other household characteristics. Other common causes of anaemia such as hookworm infestation and sickle cell disease were not determined in this study.

There are few longitudinal malaria entomology studies carried out in mining communities in Ghana and other parts of the world. The abundance of mosquitoes in the Asutifi and Tano N/S districts differed slightly due to several contributing factors. Unlike Asutifi where the mosquito abundance was highest in the impact area, Tano experienced the reverse within the six month surveyed period. Though reasons for these differences in vector densities were not investigated, they may be attributed to environmental factors, such as changes in climate or vegetation, rainfall pattern, temperature; human factors such as human created breeding sites from urbanization; and intrinsic vector characteristics as previously reported [31,32].

The EIRs calculated in this survey were as high as the EIRs found in the Kintampo area $(269 i b / p / y)$ two years prior to this survey and used as an estimate for the control. The high EIRs recorded occurred in months that experienced moderate rainfall; June-July in Asutifi and February-May in Tano N/S, which indicates the impact of rainfall in vector populations and their breeding potential. Moderate rainfall creates pockets of water which favours breeding of larvae unlike torrential rains which washes away larval breeding sites of the major malaria vectors in Africa [32]. As such, changes in vegetation or environment that promotes moderate rainfall could possibly begin to experience high malaria transmission if appropriate vector control activities are not planned. EIRs varied significantly between areas or communities and, therefore, control strategies need to be planned in concert with detail area vector indices such as abundance, speciation and EIRs. The low infectivity rate of $A n$. funestus in this survey may probably be because a large proportion of young vectors with a low potential to transmit malaria may have been caught in the light traps; however this could not be confirmed since samples were not subjected to physiological age grading technique (parity detection) in this study. All An. gambiae s. $l$. analysed by PCR were of the S-molecular forms which is widespread in West Africa and other parts of Africa including the Kintampo area estimated for the control area [31-35].

The high percentage of $k d r+$ mutation reported in this study should prompt the malaria control programme to mount a surveillance on insecticide resistance existing especially since there could be an exacerbation due to the potential of cross-resistance between the insecticides used for farming and ITNs in this predominantly farming area.

At the time of the survey in 2006, the study area in the Asutifi and Tano N/S districts were being prepared for mining activities by Newmont Ghana Gold Limited. Part of the mining preparatory activities may include clearing away some forest vegetation that could potentially lead to clean water pools and subsequently change the breeding characteristics for mosquitoes that could transmit malaria and other vector borne diseases such as Yellow fever and Dengue if left unmanaged. This phenomenon of mosquito scourge associated with industrial activities was reported many years ago in the Panama Canal [36] and recently in the copper mines of DRC and Zambia $[37,38]$. In both cases, the industrial activity was significantly affected until an effective malaria control programme including environmental vector control was implemented. In the Zambian case, copper production increased significantly with declining burden of malaria, thus paying off the investment made in the malaria control. Additionally, a mining area has the potential of attracting migrant workers which increases the population with poor sanitation if uncontrolled.

This malaria survey was conducted as part of preparatory activities to control malaria and other potential vector borne diseases in the area. It demonstrates the mining company's commitment in controlling malaria in their area of operations while protecting its workforce to minimize cost due to healthcare and maximize productivity. Newmont Ghana Gold Limited and the Ghana Health Service have intensified malaria control activities in the area since the completion of the survey. These activities include in-door residual spraying, larviciding, free ITN distribution to employees (three ITNs per employee) and community members (two ITNs per household); refurbishment of a community health centre and training of health staff 
for accurate malaria diagnosis [39]. The impact of the interventions in the community is yet to be evaluated; however, a marked decrease ( $8 \%$ in 2006 to $1.8 \%$ in 2009) in malaria incidence among the mining work force has been noted [40]. Newmont Ghana Gold Limited's support to control malaria and other public health diseases, such as tuberculosis and HIV/AIDS, has been recognized by the Global Business Coalition on HIV/AIDS, Tuberculosis and Malaria in 2010 [40]. Similar private cooperate involvement in malaria control has successfully been supported by companies, such as Anglogold Ashanti in Obuasi area of Ghana [9], Konkola Copper Mine in Zambia [41] and Exxon Mobil in Angola, Cameroon, Chad, Equatorial Guinea and Nigeria [42].

\section{Conclusion}

The malaria epidemiology suggests a high malaria transmission in the mining area prior to the start of mining activities. Efforts at controlling malaria in this mining area have been intensified but could be enhanced with increased resources and partnerships between government and the private sector. Periodic evaluations will be key to ascertain the impact of the malaria control activities currently ongoing in the mining area.

\begin{abstract}
Acknowledgements
We are extremely grateful to the participants, parents of the young children involved as well as the community opinion leaders for their interest and support. We are thankful to the Ghana Health Service, especially Prof Agyeman Badu Akosa, former Director-General of Ghana Health Service; Alhaj (Dr) Bin Ibrahim, former Brong Ahafo Regional Director of Health Services, Dr. George Bonsu, former Brong Ahafo Regional Deputy-Director in charge of Public Health; and The District/Municipal Directors for Asutifi, Tano North, Tano South and Techiman study areas. We are appreciative of the support provided by the management of Newmont Ghana Gold Limited for the conduct of the study. We are grateful to the management and staff of Kintampo Health Research Centre and scientist who contributed to the conduct of the study, analysis and report writing.

Kintampo Health Research Centre is a member of the INDEPTH Network
\end{abstract}

\section{Author details}

${ }^{1}$ Kintampo Health Research Centre, Ghana Health Service, Ministry of Health, P. O. Box 200, Kintampo, Ghana. ${ }^{2}$ College of Health Sciences, University of Ghana, Legon, Ghana. ${ }^{3}$ Newmont Ghana Gold Limited C825/26 Lagos Avenue East, Legon, Accra, Ghana. ${ }^{4}$ INDEPTH Network Secretariat, 11 Mensah Wood Street, East Legon P. O. Box KD 213, Kanda, Accra, Ghana. ${ }^{5}$ HealthLink Consulting P.O. Box AN 6811, Accra-North Ghana. ${ }^{6}$ Newfields 730 17th Street Suite 925 Denver, CO 80202, USA.

\section{Authors' contributions}

KPA led in the proposal writing with contribution from $C M, C Z, G K, K T, D D$ and SOA. KPA, CZ, DD, and KT coordinated the data collection during the study with support from YAD and CA on behalf of Newmont Ghana Gold Limited. Laboratory analysis was performed by DBD, CB, KT and DD. Data management and analysis was done by KPA, GD, MA, SAE and SOA. KPA wrote the manuscript with contribution from all authors. All authors read the final version of the manuscript.

\section{Competing interests}

The authors declare that they have no competing interests.
Received: 26 February 2011 Accepted: 29 July 2011

Published: 29 July 2011

\section{References}

1. Snow RW, Guerra CA, Noor AM, Myint HY, Hay SI: The global distribution of clinical episodes of Plasmodium falciparum malaria. Nature 2005, 434:214-217.

2. WHO: World Malaria Report. World Health Organization; 2009.

3. Owusu-Agyei S, Asante KP, Adjuik M, Adjei G, Awini E, Adams M, Newton S, Dosoo D, Dery D, Agyeman-Budu A, Gyapong J, Greenwood B, Chandramohan D: Epidemiology of malaria in the forest-savanna transitional zone of Ghana. Malar J 2009, 8:220.

4. Bhattarai A, Ali AS, Kachur SP, Martensson A, Abbas AK, Khatib R, AlMafazy AW, Ramsan M, Rotllant G, Gerstenmaier JF, Molteni F, Abdulla S, Montgomery SM, Kaneko A, Bjorkman A: Impact of artemisinin-based combination therapy and insecticide-treated nets on malaria burden in Zanzibar. PLoS Med 2007, 4:e309.

5. Okech BA, Mwobobia IK, Kamau A, Muiruri S, Mutiso N, Nyambura J, Mwatele C, Amano T, Mwandawiro CS: Use of integrated malaria management reduces malaria in Kenya. PLOS ONE 2008, 3:e4050.

6. O'Meara WP, Bejon P, Mwangi TW, Okiro EA, Peshu N, Snow RW, Newton CR, Marsh K: Effect of a fall in malaria transmission on morbidity and mortality in Kilifi, Kenya. Lancet 2008, 372:1555-1562.

7. Mmbando BP, Vestergaard LS, Kitua AY, Lemnge MM, Theander TG, Lusingu JP: A progressive declining in the burden of malaria in northeastern Tanzania. Malar J 2010, 9:216.

8. Newmont Ghana Gold Limited. [http://www.newmontghana.com/].

9. Obuasi malaria control programme: a model for Africa. Obuasi malaria control programme: a model for Africa. AngloGold Ashanti 2007.

10. Gilles MT, DeMeillon B: The Anophelinae of Africa South of Sahara (Ethiopian Zoogeographical Region). Publication of the South African Institute for Medical Research 1968, 54:127-150.

11. Wirtz RA, Zavala F, Charoenvit Y, Campbell GH, Burkot TR, Schneider Esser KM, Beaudoin RL, Andre RG: Comparative testing of monoclonal antibodies against Plasmodium falciparum sporozoites for ELISA development. Bull World Health Organ 1987, 65:39-45.

12. Martinez-Torres D, Chandre F, Williamson MS, Darriet F, Berge JB, Devonshire AL, Guillet P, Pasteur N, Pauron D: Molecular characterization of pyrethroid knockdown resistance $(\mathrm{kdr})$ in the major malaria vector Anopheles gambiae s.s. Insect Mol Biol 1998, 7:179-184.

13. Weill M, Chandre F, Brengues C, Manguin S, Akogbeto M, Pasteur N, Guillet P, Raymond M: The kdr mutation occurs in the Mopti form of Anopheles gambiae s.s. through introgression. Insect Mol Biol 2000, 9:451-455.

14. Favia G, della Torre A, Bagayoko M, Lanfrancotti A, Sagnon N, Toure YT, Coluzzi M: Molecular identification of sympatric chromosomal forms of Anopheles gambiae and further evidence of their reproductive isolation. Insect Mol Biol 1997, 6:377-383.

15. Ehrhardt S, Burchard GD, Mantel C, Cramer JP, Kaiser S, Kubo M, Otchwemah RN, Bienzle U, Mockenhaupt FP: Malaria, anemia, and malnutrition in african children-defining intervention priorities. I Infect Dis 2006, 194:108-114.

16. Owusu-Agyei S, Fryauff DJ, Chandramohan D, Koram KA, Binka FN, Nkrumah FK, Utz GC, Hoffman SL: Characteristics of severe anemia and its association with malaria in young children of the Kassena-Nankana District of northern Ghana. Am J Trop Med Hyg 2002, 67:371-377.

17. Ronald LA, Kenny SL, Klinkenberg E, Akoto AO, Boakye I, Barnish G, Donnelly MJ: Malaria and anaemia among children in two communities of Kumasi, Ghana: a cross-sectional survey. Malar J 2006, 5:105.

18. Deribew A, Alemseged F, Tessema F, Sena L, Birhanu Z, Zeynudin A, Sudhakar M, Abdo N, Deribe K, Biadgilign S: Malaria and under-nutrition: a community based study among under-five children at risk of malaria, south-west Ethiopia. PLoS One 2010, 5:e10775.

19. Crookston BT, Alder SC, Boakye I, Merrill RM, Amuasi JH, Porucznik CA Stanford JB, Dickerson TT, Dearden KA, Hale DC, Sylverken J, Snow BS, OseiAkoto A, Ansong D: Exploring the relationship between chronic undernutrition and asymptomatic malaria in Ghanaian children. Malar 2010, 9:39.

20. Custodio E, Descalzo MA, Villamor E, Molina L, Sanchez I, Lwanga M, Bernis C, Benito A, Roche J: Nutritional and socio-economic factors associated with Plasmodium falciparum infection in children from 
Equatorial Guinea: results from a nationally representative survey. Malar J 2009, 8:225.

21. Friedman JF, Kwena AM, Mirel LB, Kariuki SK, Terlouw DJ, PhillipsHoward PA, Hawley WA, Nahlen BL, Shi YP, ter Kuile FO: Malaria and nutritional status among pre-school children: results from cross-sectional surveys in western Kenya. Am J Trop Med Hyg 2005, 73:698-704.

22. Caulfield LE, Richard SA, Black RE: Undernutrition as an underlying cause of malaria morbidity and mortality in children less than five years old. Am J Trop Med Hyg 2004, 71:55-63.

23. Binka FN, Kubaje A, Adjuik M, Williams LA, Lengeler C, Maude GH, Armah GE, Kajihara B, Adiamah JH, Smith PG: Impact of permethrin impregnated bednets on child mortality in Kassena-Nankana district, Ghana: a randomized controlled trial. Trop Med Int Health 1996, 1:147-154.

24. Fegan GW, Noor AM, Akhwale WS, Cousens S, Snow RW: Effect of expanded insecticide-treated bednet coverage on child survival in rural Kenya: a longitudinal study. Lancet 2007, 370:1035-1039.

25. AED NetMark. [http://www.netmarkafrica.org/countries/ghana/].

26. Ghana Demographic and Health Survey 2008. Ghana Demographic and Health Survey 2008 Ghana Statistical Service; Ghana Health Service, ICF Macro; 2009

27. Rashed S, Johnson H, Dongier P, Moreau R, Lee C, Crepeau R, Lambert J, Jefremovas V, Schaffer C: Determinants of the Permethrin Impregnated Bednets (PIB) in the Republic of Benin: the role of women in the acquisition and utilization of PIBs. Soc Sci Med 1999, 49:993-1005.

28. Koram KA, Owusu-Agyei S, Fryauff DJ, Anto F, Atuguba F, Hodgson A, Hoffman SL, Nkrumah FK: Seasonal profiles of malaria infection, anaemia, and bednet use among age groups and communities in northern Ghana. Trop Med Int Health 2003, 8:793-802.

29. Premji Z, Hamisi Y, Shiff C, Minjas J, Lubega P, Makwaya C: Anaemia and Plasmodium falciparum infections among young children in an holoendemic area, Bagamoyo, Tanzania. Acta Trop 1995, 59:55-64.

30. Newton CR, Warn PA, Winstanley PA, Peshu N, Snow RW, Pasvol G, Marsh K: Severe anaemia in children living in a malaria endemic area of Kenya. Trop Med Int Health 1997, 2:165-178.

31. Hay SI, Guerra CA, Tatem AJ, Atkinson PM, Snow RW: Urbanization, malaria transmission and disease burden in Africa. Nat Rev Microbiol 2005, 3:81-90

32. Kelly-Hope L, Hemingway J, McKenzie FE: Environmental factors associated with the malaria vectors Anopheles gambiae and Anopheles funestus in Kenya. Malar J 2009, 8:268.

33. Simard F, Ayala D, Kamdem GC, Pombi M, Etouna J, Ose K, Fotsing JM, Fontenille D, Besansky NJ, Costantini C: Ecological niche partitioning between Anopheles gambiae molecular forms in Cameroon: the ecological side of speciation. BMC Ecol 2009, 9:17.

34. Dery DB, Brown C, Asante KP, Adams M, Dosoo D, Amenga-Etego S, Wilson M, Chandramohan D, Greenwood B, Owusu-Agyei S: Patterns and seasonality of malaria transmission in the forest-savannah transitional zones of Ghana. Malar J 2010, 9:314.

35. Fanello C, Petrarca V, della Torre A, Santolamazza F, Dolo G, Coulibaly M, Alloueche A, Curtis CF, Toure YT, Coluzzi M: The pyrethroid knock-down resistance gene in the Anopheles gambiae complex in Mali and further indication of incipient speciation within An. gambiae s.s. Insect Mol Biol 2003, 12:241-245.

36. Sutter PS: Nature's agents or agents of empire? Entomological workers and environmental change during the construction of the Panama Canal. Isis 2007, 98:724-754.

37. Utzinger J, Tozan Y, Doumani F, Singer BH: The economic payoffs of integrated malaria control in the Zambian copperbelt between 1930 and 1950. Trop Med Int Health 2002, 7:657-677.

38. Utzinger J, Tozan Y, Singer BH: Efficacy and cost-effectiveness of environmental management for malaria control. Trop Med Int Health 2001, 6:677-687.

39. Report on Newmont Ahafo Malaria Control Programmes. Workplace And Community Health Programmes Unit Community Development, Newmont Ghana Gold Limited; 2011.

40. Global Business Coalition on HIV/AIDs, Tuberculosis and Malaria. [http:// www.gbcimpact.org/itcs_node/9/13/award/2621].

41. Sharp B, van Wyk P, Sikasote JB, Banda P, Kleinschmidt I: Malaria control by residual insecticide spraying in Chingola and Chililabombwe, Copperbelt Province, Zambia. Trop Med Int Health 2002, 7:732-736.
42. ExxonMobil Malaria Initiative. [http://www.exxonmobil.com/Corporate/ community_malaria_initiative.aspx].

doi:10.1186/1475-2875-10-211

Cite this article as: Asante et al: Malaria epidemiology in the Ahafo area of Ghana. Malaria Journal 2011 10:211.

\section{Submit your next manuscript to BioMed Central and take full advantage of:}

- Convenient online submission

- Thorough peer review

- No space constraints or color figure charges

- Immediate publication on acceptance

- Inclusion in PubMed, CAS, Scopus and Google Scholar

- Research which is freely available for redistribution

Submit your manuscript at www.biomedcentral.com/submit
Biomed Central 